\title{
WARNA ISLAM DALAM TEKS KLASIK \\ LAYANG MURSADA PESISIRAN
}

\author{
oleh Venny Indria Ekowati
}

FBS Universitas Negeri Yogyakarta

\begin{abstract}
This article is about a study conducted to describe the visualization of Islamic colors (or nuances) in Layang Mursada Pesisiran, one of the classical texts resulting from the development of coastal literary work.

Layang Mursada Pesisiran, the subject of the study, was written (or, rather, copied from the original) in 1879 and published by Badan Pekerja Kongres Bahasa Jawa, a working body for a congress on the Javanese language. The manuscript was edited by Bambang Purnomo and transliterated by Suwarni and Ratih Retno Hartati in 2001. The data for the study were obtained by repeated text reading. Words, phrases, and sentences in the text containing Islamic colors were written down and analyzed descriptively and referentially by referring to verses in the Al Quran.

Results of the study indicate the occurrence of visualization of Islamic colors in the form of (1) concept of Allah as God with praised character qualities, (2) belief in the Prophet Muhammad, the Prophet Sulaiman, and Khulafaur Rasyiidin, (3) concept of heaven and belief in the non-physical substance of angels, spirits, and devils, (4) acknowledged presence of social figures characteristic of Islam who take care of religious matters such as the pangulu, marbotoh, ketib, and modin, (5) concept of the unbeliever, and (6) commandment to the unbeliever to pray.
\end{abstract}

Keywords: Islamic colors, Islamic concepts

\section{A. PENDAHULUAN}

Agama Islam mulai dikenal oleh masyarakat Nusantara kurang lebih pada abad ke-9 Masehi (M). Beberapa abad berikutnya, kontak komunitas Nusantara ini semakin berkembang dengan adanya aktivitas perdagangan. Pada masa ini pedagang asing yang beragama Islam bergaul lebih intens dengan masyarakat Nusantara. Kemudian pada abad ke-15 dan 16, agama Islam semakin menyebar luas dan berkembang pesat dengan peranan para wali yang membentuk basis utama di daerah Pesisir Pulau Jawa seperti Tuban, Gresik, Jepara, Demak, Cirebon, Banten, dan lain-lain (Pigeaud dalam Nugroho, 2000: 23).
Tumbuh dan berkembangnya agama Islam tersebut membawa pengaruh dalam berbagai aspek kehidupan masyarakat. Salah satu pengaruh yang signifikan tampak dalam aspek sastra. Warna Islam tampak secara nyata dalam berbagai karya sastra. Basis para wali yang berada di daerah Pesisiran pun dalam perkembangannya kemudian, membentuk suatu skriptoria yang disebut dengan skriptoria Pesisiran. Karya sastra pesisiran ini pada awal perkembangannnya cenderung bersifat mistisreligius yang diramu dalam bentuk prosa liris ataupun tembang Macapat. Sifat mistis-religius ini kemudian berkembang menjadi karya yang lebih kompleks dengan pengadaptasian unsurunsur budaya yang diberi warna-warna Islami (Purnomo, 2001:2). 
Tulisan ini akan mengkaji salah satu hasil perkembangan karya sastra pesisiran yang berjudul Layang Mursada. Karya ini ditulis kurang lebih pada tahun 1879 M (abad ke-19). Tulisan ini bertujuan untuk mendeskripsikan visualisasi warna Islam dalam teks klasik Layang Mursada (LM).

\section{B. DESKRIPSI TEKS KLASIK LAYANG MURSADA}

Teks LM merupakan teks epik yang sangat digemari pada masanya. Teks LM berkembang bersama-sama dengan teks Menak. Jika teks Menak diadaptasi dari sejarah lokal Arab-Persia, teks LM muncul dari penciptaan sastrawan lokal Jawa (Purnomo, 2001: 3-4). Tulisan ini bersumber dari teks LM hasil suntingan S. Bambang Purnomo (2001). Teks LM digubah dalam bentuk tembang Macapat yang terdiri dari 13 pupuh, yaitu Asmaradana, Pangkur, Sinom, Durma, Dhandhanggula, Asmaradana, Sinom, Durma, Dhandhanggula, Asmaradana, Pangkur, Durma, dan Asmaradana.

Suntingan didasarkan pada empat buah naskah LM yang berasal dari Tuban dan Lamongan. Naskah-naskah ini ditulis dengan aksara Jawa dan Pegon. Tahun penyalinan berkisar pada tahun $1879 \mathrm{M}$. Identifikasi warna Islam dalam teks LM dilakukan dengan pembacaan berulang-ulang teks LM. Kata, frasa, kalimat yang mengandung warna Islam dicatat dan dianalisis secara deskriptif.

\section{Islam dalam Karya-Karya Sastra Jawa}

Islam mulai berkembang di Indonesia semenjak abad ke-13 M. Namun baru pada abad ke-16 sampai dengan $17 \mathrm{M}$, warna Islam mulai berpengaruh dalam karya-karya sastra, baik sastra Melayu maupun sastra Jawa (Sedyawati, 2001: 424-425). Mulai abad ke-17 tepatnya mulai tahun 1651 sampai awal abad ke-20, kerajaan-kerajaan di Jawa yang sudah terpengaruh oleh Islam juga terpengaruh oleh bangsa Barat, mengingat bangsa Eropa mulai melakukan ekspansi ke Kerajaan Banten. Penjajahan bangsa Potugis, Belanda, dan Jepang yang berlangsung berturut-turut ini juga merupakan faktor ekstrinsik yang mempengaruhi karya sastra yang diciptakan pada masa tersebut.

Naskah Jawa pada masa itu ditulis dengan aksara Jawa, mengadaptasi ayat-ayat dalam bahasa Arab dan ditulis sesuai dengan ejaan Jawa. Islam dalam karya-karya sastra Jawa pada awal masa perkembangannya, berisi buah pikiran ortodoks, baik itu Hinduisme, Buddhisme, ataupun Islam. Hasil karya sastra mendapat pengaruh Islam tampak secara jelas dalam struktur ekstra estetiknya. Berikut ini contoh karya Jawa yang terpengaruh ajaran Islam dalam kerangka sejarah periode Islam:

\begin{tabular}{|c|l|l|}
\hline No & Kerajaan & \multicolumn{1}{c|}{ Karya Sastra yang Muncul } \\
\hline 1. & Demak (Islam) & $\begin{array}{l}\text { Het Boek van Bonang, Een Javans Geschrift uit de 16e eeuw, } \\
\text { Suluk Sukarsa, Kodja Jajahan, }\end{array}$ \\
\hline 2. & Mataram II & $\begin{array}{l}\text { Suluk Wujil, Suluk Malang Sumirang, Nitisruti, Nitipraja, } \\
\text { Sastragending, Suluk Sewaka, }\end{array}$ \\
\hline 3. & Kartasura & Serat Menak, Rengganis, Manik Maya, Ambiya, Kandha \\
\hline
\end{tabular}

Karya-karya sastra di atas mengandung struktur estetik sebagai berikut: (1) terpengaruh oleh unsur Islam, yang masih taat dan menggunakan tembang Macapat dalam karya sastranya. Dengan kata lain disebut puisi Islam atau suluk, (2) pilihan kata sudah cenderung lugas, (3) guru lagu dan guru wilangan merupakan salah satu sarana kepuitisan yang utama, dan (4) menggunakan bahasa yang berciri baru, yang merupakan perpindahan dari bahasa Jawa tengahan ke bahasa Jawa baru. 
Sedangkan struktur ekstra estetiknya sebagai berikut: (1) membahas masalah yang dibahas berkisar pada ajaran mistik, asal mula dunia, serta kisah para nabi, dan (2) ide-idenya bersifat religius

Karya Sastra pada masa ini sangat jelas terpengaruh oleh Islam, hal ini sangat wajar, karena sentra budaya pada periode Jawa tengahan, yaitu Majapahit sudah runtuh. Pusat perdagangan semakin meluas dan berkembang di daerah-daerah pesisir. Hal ini semakin mendatangkan banyak pedagang Islam yang berasal dari Persia yang membaur dengan para pedagang Gujarat dengan paham Hindunya. Sehingga percampuran ini membuat suatu karya sastra yang unik dan mempunyai ciri khas tersendiri yang sering disebut dengan Mistis Jawa.Warna Islam berlanjut sampai dengan periode Surakarta awal yang tetap didominasi oleh bentuk tembang. Pada masa ini, karya sastra sudah tidak banyak terpengaruh oleh unsur Islam, tetapi masih ada ciri ke-Islaman dalam karya-karyanya.

Penerimaan Islam oleh masyarakat Jawa sering melalui proses tarik-menarik dengan budaya Jawa, oleh karena itu karya sastra yang timbul juga merepresentasikan adanya proses seleksi, kontekstualisasi, dan internalisasi terhadap ajaran Islam, sesuai dengan sistem budaya Jawa. Proses ini membentuk corak lokal khas yang juga tercermin dalam karya-karya sastra yang terpengaruh Islam (Fathurahman, 2004: 6-9).

Layang Mursada juga merupakan teks sastra Jawa yang bernafaskan Islam. Menurut Sudikan (dalam Purnomo, 2001: v), teks LM merupakan hasil karya sastra Jawa dari zaman Islam awal. Naskah ini kemudian menjiwai karya sastra Jawa sesudahnya, misalnya Iman Sujana dan Serat Jatiswara. Teks LM tampak sebagai karya sastra awal masa Islam, karena dalam kisahnya masih terpengaruh konsepkonsep yang disesuaikan dengan sistem budaya Jawa (Jawa-Hindu). Misalnya masih adanya konsep karma, tirakat, tapa brata, konsep kadewatan, peri perayangan, serta kepercayaan terhadapjimat dan ajian.

\section{Daerah Pesisir sebagai Skriptorium Karya Sastra Pesisiran}

Penyebaran agama Islam di pulau Jawa, tidak semulus di luar pula Jawa. Ajaran Islam semula tidak dapat menembus kuatnya pengaruh budaya Kraton Hindu-Jawa. Para petinggi kraton pada masa itu menganggap budaya Islam masih rendah dan kearab-araban. Oleh karena itu, selama beberapa abad, penyebaran Islam merangkak terlebih dahulu di daerah-daerah pedesaan, terutama di sepanjang pesisir. Daerah pesisir ini kemudian berkembang pesat menjadi kerajaan-kerajaan kecil yang menjadi pusat pendidikan agama dan menjadi mitra bagi lingkungan budaya kraton Hindu. Daerah pesisir ini kemudian juga menjadi penghasil karya-karya sastra yang dikenal dengan karya sastra pesisiran yang kental dengan muatan Islam (Sedyawati, 2001: 425).

Pigeaud dalam Literature of Java Vol. I (1967), menyatakan bahwa daerah Pesisir mulai menjadi skriptorium karya sastra Jawa pesisiran mulai abad ke-15 M. Periode sastra Jawa pesisir berkembang pesat dengan pusatpusat di pantai utara, di Surabaya-Gresik, Demak-Jepara, terus ke barat sampai ke Cirebon dan Banten. Dalam perkembangannya, sastra Jawa pesisiran meluas ke barat sampai Palembang dan Lampung, ke timur sampai ke Lombok, dan ke utara sampai Banjarmasin.

Karya sastra yang bernafaskan Islam Het Boek van Bonang 'kitab Bonang dan Een Javans Geschrift uit de 16e eeue 'Primbon Abad ke-16' merupakan karya sastra yang merupakan tonggak berkembangnya sastra Jawa Pesisiran. Selanjutnya skriptorium Pesisiran ini menghasilkan karya-karya sastra dengan warna Islam, yang menyatakan sikap keagamaan masyarakat Pesisir yang tertuang melalui bahasa estetik. Karya-karya yang muncul misalnya Suluk Tembangraras, Sukarsa, Wujil, Suluk Sujinah, Suluk Dhudha, dan lain-lain.

\section{Ciri Karya Sasta Pesisiran}

Karya sastra Jawa Pesisiran pada masa perkembangannya mempunyai ciri cenderung 
bersifat mistis religius dalam bentuk prosa liris atau tembang Macapat. Masa berikutnya menjadi karya yang lebih kompleks dengan adaptasi Jawa-Hindu yang diberi warna Islami. Karya sastra pesisiran dalam perkembangannya dapat dipilah menjadi tiga ciri kelompok. Kelompok tersebut antara lain: (1) karya yang mengandung tema etik religius yang ortodok dan mengedepankan syariat Islam, (2) karyakarya yang berupa puisi naratif didaktis; dan (3) karya-karya mistik. Teks LM sendiri lebih condong pada kisah naratif didaktif yang mengisahkan perjuangan dan kerja keras Raden Mursada. Hidupnya yang penuh penderitaan akhirnya mampu diatasi dan berhasil diangkat menjadi raja.

Karya sastra Jawa pesisiran juga mempunyai ciri khas dalam struktur estetisnya. Sebagian besar karya pesisiran, digubah dalam bentuk tembang Macapat (Purnomo, 1992). Selain struktur estetis, naskah-naskah pesisiran juga mempunyai ciri khas dalam segi ejaan. Penambahan dan pengurangan bunyi nasal merupakan salah satu ciri pemakaian ejaan atau tulisan jenis Pesisir (Behrend, 1990: 516). Bunyi nasal yang dihilangkan tersebut biasanya adalah cêcak (ng). Pemakaian ejaan atau tulisan jenis Pesisir ini sering disebut dengan gaya ortografik pélo pilêg, yaitu bahasa Jawa yang ditulis dengan menghilangkan huruf sengau sehingga bunyinya tidak sempurna, seperti orang pilek' (Behrend, 1995: 660).

Ciri lain ejaan pesisir ini adalah penggantian vokal è, é menjadi "i" atau sebaliknya, dari "i” menjadi é, è. Kasus ini timbul sebagai akibat transkripsi antara manuskrip pégon dan aksara Jawi. Aksara "ya" dalam pegon, digunakan untuk mewakili vokal è, é, maupun "i”, sehingga dapat menimbulkan variasi dalam proses transkripsi (Behrend, 1995: 53).

\section{WARNA ISLAM YANG TERDAPAT DALAM TEKS LAYANG MURSADA}

Warna Islam yang terdapat dalam teks LM akan dibahas secara urut berdasarkan pupuh, pada 'bait', dan gatra 'baris'. Angka romawi pada pembahasan melambangkan pupuh, angka Arab menunjukkan pada, dan huruf Latin kecil menunjukkan letak baris.

\section{Teks LM Pupuh I, Pada 1a-e}

Ingsun amimiti amuji, anebut asmaning Allah, kang murah ing donya mangko, kang pinuji datan pegat, ingkang asih ing akhirat, kang angganjar kawlas ayun, angapura wong kang dosa

'kubuka tembang ini dengan memuji, menyebut Asma Allah, Yang Pemurah di dunia ini, yang selalu Terpuji tanpa berkesudahan, Maha Pengasih di akherat kelak, 'Maha Pengasih di akherat kelak, yang menganugerahkan belas kasih, mengampuni mereka yang berdosa'

Berdasarkan bait di atas, dapat dilihat adanya warna Islami. Teks ini mengadaptasi ajaran dalam agama Islam untuk memulai semua hal yang baik dengan menyebut nama Allah. Allah adalah sang Maha Pencipta yang menciptakan semua isi alam. Allah adalah dzat yang Maha Tahu. Bait di atas juga menyebutkan puji-pujian yang berupa sifat-sifat Allah, di antaranya adalah Maha Pemurah, Maha Terpuji, Maha Kekal, Maha Pengasih, dan Maha Pengampun. Beberapa rujukan dalam bait di atas dapat dijumpai dalam Alquran, Surat Al-Fatihah: 1 yang berbunyi bismillaahirrahmaanirrahiim 'Dengan nama Allah Yang Maha Pemurah lagi Maha Penyayang'. Sifatsifat Allah yang lain, sesuai dengan bunyi bait di atas, dapat ditemui pula dalam ayat-ayat Alqur'an sebagai berikut: "Katakanlah: Jika kamu benar-benar mencintai Allah, ikutilah aku, niscaya Allah mengasihi dan mengampuni dosa-dosamu. Allah Maha Pengampun lagi Maha Penyayang" (Ali Imran: 31). Terdapat pula dalam QS. Faathir: 15 yang diterjemahkan sebagai berikut. "Hai manusia, kamulah yang berkehendak kepada Allah, dan Allah Dialah Yang Maha Kaya lagi Maha Terpuji." Pada bait ini juga terdapat adanya konsep-konsep Islam, yaitu konsep mengenai dosa dan akherat. Konsep mengenai akherat memang terdapat dalam Alquran di antaranya pada QS. Al A'la 
dan Al-Hadid. Teks LM juga mengenal konsep mengenai dosa yang merupakan kebalikan dari pahala. Pada prinsipnya, dosa akan disandang oleh umat manusia jika melakukan laranganlarangan Tuhan.

\section{Teks LM Pupuh I, Pada 2a-b}

Sampun amuji Hyang Widdhi, amuji Nabi Muhammad,....

'Setelah memuji Yang Maha Kuasa, lalu memuji Nabi Muhammad, ...

Warna Islam dalam teks LM juga tampak dengan adanya pujian bagi Nabi Muhammad. Kepercayaan dan pujian kepada Nabi Muhammad mengacu pada Qur'an Surat Al-Fath: 29 dengan diterjemahkan sebagai berikut:

Muhammad itu adalah utusan Allah dan orang-orang yang bersama dengannya adalah keras terhadap orang-orang kafir, tetapi berkasih sayang sesama mereka: kamu lihat mereka ruku' dan sujud mencari kurnia Allah dan keridhoan-Nya, tanda-tanda mereka tampak pada muka mereka dari bekas sujud....

\section{Teks LM Pupuh I, Pada 2c-g}

lawan para Sekabate, sekabat sekawan nika, ingkang dhihin Abubakar, loro Umar Usman telu, sekawan Ali Bagendha

'bersama para sahabat, yakni keempat sahabat, pertama Abubakar, kedua Umar dan ketiga Usman, keempat Baginda Ali'

Empat sahabat nabi yang disebut dalam teks LM adalah khalifah Islam yang menggantikan Nabi. Mereka disebut khulafaur raasyidiin, artinya para khalifah yang mermperoleh petunjuk. Gelar tersebut diberikan karena mereka selalu berusaha mengikuti jejak Rasulullah dalam segala hal. Khalifah ialah pimpinan umum kenegaraan untuk rakyat buat membawa mereka kepada agama yang suci, menekan golongan yang kuat jangan sampai berbuat sewenang-wenang terhadap golongan yang lemah di dalam tugas kewajibannya dalam negara. Terhadap pihak luar, dia melindungi agama Islam dan menolak serangan dari luar, dan dia tidaklah dapat berdiri melainkan dengan kemauan rakyat.

Empat sahabat Nabi tersebut yaitu: Sayidina Abu Bakar adalah khalifah Islam pertama yang menggantikan Nabi. Abu Bakar Ali adalah orang yang paling terpercaya, dan pembantu nabi yang paling setia. Dilahirkan di Makkah dua setengah tahun setelah tahun Gajah, atau lima puluh setengah tahun sebelum dimulainya hijrah. Di masa pra Islam dikenal sebagai Abul Ka'ab dan waktu masuk Islam, Nabi memberinya nama Abdullah dengan gelar ash-Shiddiq 'orang terpercaya'. Sahabat Nabi yang kedua adalah Umar bin Khatthab yang sekaligus menjadikan khalifah kedua setelah Abu Bakar. Sahabat nabi yang ketiga sekaligus khalifah ketiga setelah Abu Bakar adalah Usman bin Affan, dan khalifah yang keempat adalah Ali bin Abi Thalib.

\section{Teks LM Pupuh II, Pada 28d}

Takona guru kang nyata, endi gongone sukma kang pati sejati, yen weruha ta puniku, pinaringan swarga padhang, merga iku tunggal sejatine ngelmu, kang aran Bental Mukadas, panggenan guru sejati

'Bertanyalah kepada Guru yang benar, di manakah tempat suksma yang hakiki, jika memahami hal itu, dianugerahi sorga yang terang, sebab itu satu-satunya ilmu sejati, yang bernama Baitul Muqodas, tempat guru yang sejati'

Disebutkan dalam teks tersebut adanya konsep mengenai sorga. Bahwa sorga merupakan anugrah kepada manusia yang menyerahkan segala hal kepada Tuhan. Karena hanya kepada Tuhan manusia akan kembali, dan hanya di atas jalan-Nyalah seseorang harus beramal baik. Sorga juga merupakan imbalan yang setimpal bagi manusia yang menjalankan 
perintah Tuhan dan menjauhi laranganlarangan-Nya.

\section{Teks LM Pupuh II, Pada 30a}

Sarta lawan malaekat, ingkang mapag dhumateng Dewi Sukarsi, katrima maring Hyang Agung, ingunggahaken ana ing swarga, Retna Ayu ngungkuli sasaminipun, ya ta ing pratandhanira, wong madhep maring ing laki

'Serta bersama malaikat, yang menjemput Dewi Sukarsi, diterima di haribaan Tuhan, dinaikkan ke dalam sorga, Retna Ayu lebih dari sesamanya, sebagai pertanda adalah, orang yang setia pada suami'

Warna Islam dalam teks LM juga tampak dengan adanya kepercayaan kepada Malaikat. Acuan keimanan kepada malaikat ini dapat dilihat pada Alquran surat At-Tahriim: 6

"Wahai orang-orang yang beriman! Peliharalah diri kamu dan keluarga kamu dari neraka yang bahan-bahan bakarannya: manusia dan batu (berhala); neraka itu dijaga dan dikawal oleh malaikat-malaikat yang keras kasar (layanannya); mereka tidak menderhaka kepada Allah dalam segala yang diperintahkan-Nya kepada mereka, dan mereka pula tetap melakukan segala yang diperintahkan"

Selain itu, eksistensi malaikat dalam agama Islam juga tercermin dalam QS. AlMudatstsir: 21 yang berarti: "Dan tidaklah mereka mengetahui tentang bala tentara Allah (malaikat-malaikat) melainkan hanya Dia". Kepercayaan dan konsep tentang malaikat dalam teks LM hadir ketika Dewi Sukarsi meninggal. Dewi Sukarsi merupakan istri Raja Baitul Mukadas. Karena adanya persekongkolan di kerajaan, raja memerintahkan Arya Cengkiling untuk membunuh Dewi Sukarsi. Walaupun sudah menghunus keris, Arya Cengkiling tetap tidak tega untuk membunuh junjungannya tersebut. Akhirnya Dewi Sukarsi menabrak keris yang sudah terhunus tersebut dan akhirnya tewas. Karena kesuciannya, roh Dewi Sukarsi dijemput oleh para bidadari dan malaikat, dan selanjutnya dinaikkan menuju sorga.

\section{Teks LM Pupuh III, Pada 4a-g}

Sarupane wong kasmaran, maring sira Raden pekik, jin setan lan perayangan, gendruwo lan banaspati, padha asih aningali, sarupane kang lelembut, lanang wadon padha ngresa, rahina kalawan wingi, Raden Mursada nyata trah kusuma nata

'Semua orang menaruh sayang, pada Raden yang rupawan, jin setan, dan perayangan, gendruwo dan banaspati, kasih sayang melihatnya, segala makhluk halus, jantan betina turut menjaganya, siang dan malan, sungguh Raden Mursada keturunan raja.

Bait ini mengisahkan, putra Dewi Sukarsi yang dititipkan kapda Kyai dan Nyai Nambi, sesaat sebelum meninggal, tumbuh menjadi seorang pemuda yang tampan dan berwibawa. Laku prihatin yang dijalaninya, membuat pemuda yang diberi nama Raden Mursada semakin tampak sebagai tokoh pilihan. Cahaya pun seperti memancar di dalam dirinya. Hal inilah yang membuat manusia maupun makhluk halus jatuh cinta kepadanya. Pada kutipan bait di atas, terlihat adanya warna Islam dengan pengakuan eksistensi jin dan setan.

Pengakuan tentang zat ghaib memang telah diperintahkan Allah dalam QS. AlBaqarah: 4: "Mereka yang beriman kepada yang ghaib, yang mendirikan shalat dan menafkahkan sebagian rizki yang Kami anugerahkan kepada mereka”. Makhluk Allah yang bersifat ghaib selain malaikat adalah jin dan iblis (setan). Secara implisit, penciptaan jin termaktub dalam QS. Adz-Dzaariyaat: 60 yang artinya: "Dan tidaklah aku menjadikan jin dan manusia melainkan agar mereka beribadat 
kepada-Ku”. Dalam teks LM juga disebutkan bahwa "sarupane kang lelembut, lanang wadon padha ngresa" 'segala makhluk halus, jantan betina turut menjaganya'. Kutipan teks LM ini sesuai dengan konsep dalam Islam bahwa jin tercipta dari api yang sangat panas dan dalam golongan jin, ada yang lelaki dan ada perempuan. Jin juga berkeluarga, dan diantaranya ada mukmin dan kafir.

Teks LM juga mengenal konsep adanya setan/ iblis. Setan/ iblis merupakan makhluk gaib dari golongan jin yang murtad. Iblis pemimpin dari para setan. Setiap yang murtad dari golongan jin adalah setan, dan setiap setan adalah jin, tetapi tidak semua jin adalah setan. Rujukan mengenai kepercayaan tentang eksistensi iblis, salah satunya terdapat dalam firman Allah surat Al-A'raaf ayat 12 yang berarti:

"Apakah penghalangnya yang menyekatmu daripada sujud ketika Aku perintahmu?" Iblis menjawab: "Aku lebih baik daripada Adam, Engkau (wahai Tuhan) jadikan daku dari api sedang dia Engkau jadikan dari tanah."

Penggalan bait pada teks LM menunjukkan adanya perpaduan antara budaya Jawa dan konsep dalam Islam. Selain kepercayaan tentang adanya jin dan setan, dalam teks LM tersebut disebutkan adanya perayangan 'makhluk halus/ roh yang tinggal di tempat-tempat angker, seperti pohon dan sebagainya' (Poerwadarminta, 1939: 509). Selain itu disebutkan pula adanya makhluk halus yang disebut gendruwo 'setan yang berwujud raksasa' (Poerwadarminta, 1939: 143), dan banaspati, sebutan untuk sejenis hantu tanpa kepala. Bait ini menunjukkan bahwa Islam dan budaya Jawa hidup berdampingan. Konsep kepercayaan terhadap jin dan setan dipadu dengan berbagai jenis makhluk halus yang hidup di alam pikir orang Jawa, seperti gendruwo dan banaspati. Hal ini menunjukkan bahwa masyarakat pesisiran yang pada masa itu masih terpengaruh dengan tradisi anistis dan dinamistis, ternyata bisa menerima Islam tanpa kehilangan ciri kultural kejawaannya (Abdalla, 2005: 1-3).

\section{Teks LM Pupuh V, Pada 1-2a-g}

Wus sinegeg wahu ingkang guling, kawarnaha ing pulo Ngijerak, wonten putri ayu rupane, lir widadari tumurun, akekasih Ni Gendrasari, ayune tanpa tandhingan, sembada lan dedegipun, kuninge amonda-monda, Gendrasari lumun mesem pait gendhis, putrine Nabi Sulaeman

Rama Nabi ibunira ejin, Gendrasari dadi padhalungan, mulane ayu rupane, tur sekti bisa mabur, amarentah sagunge jin, marentah jin pitung yuta, kaprentah maring Sang Ayu, jumeneng maksih walajang, dados nata Gendrasari risang putri, dulure namung satunggal

'Sudah selesai cerita tentang orang yang tertidur, kemudian tersebutlah di pulau Ngijerak, puteri yang cantik rupanya, bagaikan bidadari yang menjelma, bernama Ni Gendrasari, cantik tiada bandingannya, selaras dengan sosok tubuhnya, kuning berkilat-kilat, jika tersenyum semanis madu, (dialah) puteri Nabi Sulaiman'

'Ayahnya seorang Nabi ibunya jin, Gendrasari jadi padhalungan, oleh karena itu cantik wajahnya, lagi pula sakti dan dapat terbang, menguasai segala jenis jin, menguasai tujuh juta jin, di bawah kekuasaan Sang Ayu, dinobatkan semenjak masih gadis, menjadi Ratu Risang Putri Gendrasari, saudaranya hanya satu'

Cerita mengenai Nabi Sulaiman dalam LM sesuai dengan cerita Nabi Sulaiman dalam ajaran Islam. Nabi Sulaiman merupakan putra Nabi Daud. Dalam teks-teks klasik Jawa, selain Nabi Muhammad, Nabi Sulaiman menjadi salah satu nabi yang banyak disebut namanya di teks-teks klasik Jawa. Hal ini dikarenakan kekuasaan Nabi Sulaiman atas jin, dan 
kemampuannya untuk memahami bahasa binatang.

Teks LM menyebutkan bahwa Nabi Sulaiman mempunyai putra dengan seorang jin wanita. Hal ini merupakan pengembangan dari acuan QS. An-Naml: 15-44. Dalam ayat ini diceritakan bahwa Nabi Sulaiman mengIslamkan ratu Balqis yang memimpin kerajaan Saba. Kerajaan ini yang sangat berkuasa, kaya, dan sangat makmur, tetapi masih menyembah matahari sebagai Tuhan. Selanjutnya dengan ijin Allah, dan dibantu oleh pasukan jin, Sulaiman mampu meyakinkan Ratu Balqis untuk memeluk agama Islam. Menurut beberapa ahli tafsir dan ahli sejarah nabi-nabi, dikatakan bahwa pada akhirnya Nabi Sulaiman memperistri Ratu Balqis dan mempunyai seorang putra.

Dua bait teks LM di atas mengandung warna Islam, tentang konsep kepercayaan kepada Nabi Sulaiman. Disebutkan dalam teks LM, Nabi Sulaiman menikah dengan seorang jin wanita dan mempunyai dua orang puteri, bernama Gendrasari dan Retnakumala. Putrinya yang bernama Gendrasari, selain cantik juga mempunyai kekuatan yang luar biasa, sehingga menjadi ratu dari tujuh juta jenis jin. Teks LM mengadopsi riwayat Nabi Sulaiman, dan mengembangkannya secara lebih mendetail mengenai istri dan puteri Nabi Sulaiman. Selanjutnya disebutkan pula bahwa Putri Gendrasari inilah yang akan menjadi istri Raden Mursada.

\section{Teks LM Pupuh V, Pada 20a-g}

Sejatine walese Hyang Widdhi, kala mateni keng garwa, punika Raden wiyose, utang pati nyaur lampus, adilira Hyang Maha Suci, utang wirang nyaur wirang, walese Hyang Agung yen saking tingal kawula, amung dika ingkang saged anambani, sakite Sri Naranata

'Sesungguhnya itu balasan Tuhan, karena membunuh permaisuri, kono karena itulah Raden, hutang mati bayar mati, keadilan Tuhan Yang Maha Suci, hutang malu bayar malu, balasan dari
Tuhan, dari pengamatan hamba, hanya Anda yang dapat mengobatinya, sakit Sri Naranata'

Teks LM pada kutipan di atas menceritakan bahwa Raja Ngerum (ayah Raden Mursada) sakit parah. Tidak ada yang seorang pun yang mampu menyembuhkannya. Warna Islam tampak dalam kutipan di atas, yaitu adanya konsep Tuhan Yang Maha Adil. Keadilan Tuhan ini, menurut teks LM disebutkan bahwa sakit yang diderita oleh Raja, merupakan hukuman dari Tuhan karena telah tega membunuh permaisurinya sendiri. Warna Islam juga tampak dengan adanya konsep Tuhan Yang Maha Suci. Acuan tentang Allah Maha Suci, dapat dilihat dalam firman Allah surat Az-Zumar: 4 yang artinya: "Kalau sekiranya Allah hendak mengambil anak, tentu Dia akan memilih apa yang dikehendaki-Nya di antara ciptaan-ciptaan yang telah diciptakanNya. Maha Suci Allah. Dialah Allah Yang Maha Esa lagi Maha Mengalahkan". Sedangkan acuan mengenai konsep Allah Maha Adil, dapat dilihat dalam Q.S. Ghafir: 20, yang berarti: Dan pula Allah Taala berfirman, "Allah memutuskan perkara dengan kebenaran (keadilan). Apa yang mereka seru (puja) selain dari Allah itu, tidaklah dapat memutuskan perkara apa pun. Sesungguhnya Allah adalah Maha Mendengar lagi Melihat."

\section{Teks LM Pupuh IX, Pada 1 a-g}

Wus sinigeg wau ingkang jurit, kawarnaha panjenengan Sri Nalendra, ginubel kang putra, Raja Sejadhi wastane, Yumani negaranipun, pan kacrita ratu sinidik, keringan manca nagara, para ratu teluk, anyelamaken wong kopar, Sri Nalendra ginubel wong dama miskin, asung sandhang wong kawudan

'Terhentilah mereka yang bertempur, tersebutlah Sang Raja, tengah dihadp putreranya, Raja Sejadi namanya, Yumani negaranya, konon disebut sebagai ratu yang sakti, terkenal ke negara tetangga, banyak raja takluk, 
meng-Islamkan orang kafir, Sang Raja disayang fakir miskin, memberi pakaian mereka yang telanjang'

Warna Islam dalam kutipan di atas, tampak pada deskripsi singkat mengenai Raja Sejadi. Berdasarkan kutipan di atas, dapat disimpulkan bahwa Raja Sejadi adalah raja dari suatu kerajaan Islam. Raja ini juga dikenal sebagai penyebar agama Islam, dan sudah banyak meng-Islamkan orang-orang kafir. Perlawanan dan perjuangan untuk mengIslamkan golongan yang masih kafir juga diceritakan dalam teks LM pupuh 12 (Durma), bait 1-45. Dalam pupuh ini diceritakan perlawanan Raja Sejadi dan Raden Mursada dalam upayanya untuk meng-Islamkan kerajaan yang dipimpin oleh Raja Ekram yang masih kafir. Akhirnya Kerajaan Ekram berhasil di-Islamkan, bahka putri Raja Ekram pun menyatakan diri masuk Islam. Konsep Islam mengenai penyebutan bagi golongan kafir sesuai dengan firman Allah dalam beberapa surat, yaitu: Al-Baqarah: 6-7, 257; Al-Maaidah: 44, 103; Al-An'aan: 1; QS An-Nisaa: 167, AlAnfaal: 36, Ar-Ra'du: 43, Al-Hajj: 55, AlFurqaan ayat: 4, dan Fushshilat: 26.

\section{Teks LM Pupuh XI, Pada 1a-g}

Pan angrasa ing sajrone ati, Dewi Suwarsi tatkalane supena, nyata Raden lamun baguse, kang rama duk andulu, maring putranira kang estri, ping kalih jodhonira, lajeng ning pangulu, sarta marbotoh pisan, ketib modin tuwa anom padha prapti, pan samiya jajar lenggah

'Namun merasa dalam hatinya, ketika Dewi Suwarsi bermimpi, nyata benar ketampanan Mursada, sang ayah ketika menyaksikan, puterinya itu, lalu pada (calon) suaminya, kemudian dihadapkan penghulu, serta para marbotoh, ketip modin tua muda berdatanga, duduk berjajar'

Kutipan di atas menunjukkan adanya warna Islam, karena adanya tata cara pernikahan secara Islam, yaitu pernikahan antara Raden Mursada dengan Dewi Suwarsih, putri Raja Sejadhi. Warna Islam tampak pada tokoh cerita dengan adanya penyebutan tokoh pangulu penghulu', marbotoh (merbot), ketib 'khatib', dan modin yang merupakan perangkat desa khas Islam. Penghulu adalah kepala urusan agama Islam di tingkat kabupaten atau kotamadya, atau penasehat urusan agama Islam di pengadilan negeri (KBBI, 1995: 748). Dalam teks LM, penghulu merupakan sebutan bagi para tokoh agama.

Marbotoh atau merbot merupakan punggawa atau pimpinan masjid (Poerwadarminta, 1939: 310). Kata ketib, berasal dari bahasa Arab. Kata ini dipakai untuk menyebut pegawai masjid, juru khotbah, atau orang yang menyampaikan khotbah pada waktu sembahyang Jum'at (KBBI, 1995: 497). Pada masyarakat pedesaan, ketib biasanya dipakai untuk menyebut pengurus masjid yang merupakan bawahan dari penghulu (Poerwadarminta, 1939: 217). Sedangkan modin adalah tukang azan, pegawai masjid, lebai atau kaum yang pekerjaannya membaca doa (Poerwadarminta, 1939: 329).

\section{Teks LM Pupuh XIII, Pada 1a-g}

Sarupane bala kapir, wus padha teluk sedaya, sarta lan raja branane, bebek ayam raja kaya, wadon miwah kang lanang, kabekta mring Yang Ngagun, sedaya kinen sembahyang.

'Semua pasukan kafir, takluklah semuanya, bersama harta kekayaannya, ayam bebek dan binatang piaraannya, betina maupun jantan, dibawa untuk korban Yang Kuasa, semua diminta sembahyang'.

Setelah berhasil meng-Islamkan kerajaan yang masih kafir, maka semua rakyat di kerajaan tersebut diperintahkan untuk menyembah Allah dengan cara melakukan sembahyang. Sembahyang dalam Islam adalah melakukan sholat lima waktu, memuji serta berdoa kepada Allah (Poerwadarminta, 1939: 555). Acuan mengenai sholat terdapat dalam 
QS. Al-Baqarah: 43 yang berbunyi: "Waaqiimushshalaata wa-aatuzzakaata warka'uuma'-arraki'iin" 'Dan dirikanlah shalat, dan keluarkanlah zakat, dan tunduklah/ ruku' bersama-sama orang-orang yang rukuk'.

\section{SIMPULAN}

Warna Islam yang tervisualisasi dalam Teks Layang Mursada Pesisiran adalah sebagai berikut:

1. Konsep Allah sebagai Tuhan yang mempunyai sifat-sifat mulia yaitu Maha Pemurah, Maha Terpuji, Maha Kekal, Maha Pengasih, dan Maha Pengampun. Maha Terpuji, Maha Penyayang, Maha Adil, Maha Pemurah, dan Maha Suci.

2. Konsep kepercayaan terhadap Nabi Muhammad, Nabi Sulaiman, dan Khulafaur Rasyiidin

3. Konsep tentang sorga, dan konsep kepercayaan terhadap penciptaan zat ghaib oleh Allah, yaitu dari golongan malaikat, jin, dan setan

4. Warna Islam juga terlihat dengan adanya tokoh-tokoh khas yang biasa mengurusi hal-hal keagamaan seperti pangulu penghulu', marbotoh (merbot), ketib 'khatib', dan modin. Selain itu, terdapat pula konsep mengenai kekafiran.

5. Cara peribadatan dengan cara Islam juga terdapat dalam teks LM, dengan adanya perintah sembahyang bagi orang-orang kafir.

\section{DAFTAR PUSTAKA}

Abdalla, Ulil Abshar. 2005. "Centhini", http://www.jawapalace.org.

Behrend, T. E. 1995. Serat Jatiswara-Struktur dan Perubahan di dalam Puisi Jawa 1600-1930 (terj. A. Ikram). Jakarta: INIS.

Fathurahman, Oman. 2004. Peta Naskah Keislamanan Nusantara: Karakteristik dan Kecenderungan.
Makalah Pelatihan Filologi Tingkat Nasional. PPM UIN Jakarta.

Nugroho, Sigit. 2000. Analisis Pragmatik Suluk Mustaka Rancang. Skripsi Fakultas Sastra UGM Yogyakarta.

Poerwadarminta, W. J. S. 1939. Baoesastra Djawa. Groningen Batavia: J. B. Wolters.

Purnomo, Bambang S. 2001. Teks Klasik dan Pesisiran dalam Naskah Lama Jawa: Layang Mursada Pesisiran. Yogyakarta: Badan Pekerja Kongres Bahasa Jawa 2001.

Sedyawati, dkk (ed). 2001. Sastra Jawa: Suatu Tinjauan Umum: Jakarta: Balai Pustaka.

Sudirman, Ahmad. 2003. "Menyorot Pergantian Kepemimpinan Khulafaur Rasyidin", http://www.dataphone.se/ ahmad. 